\title{
Assessment of College Students' Knowledge and Attitudes Toward Solid Waste Management in North Central Zone of Nigeria
}

\author{
Mohammed Dauda Dung, Mangut Mankilik, Bernadette Ebele Ozoji* \\ ${ }^{1}$ Federal College of Education, Pankshin, Nigeria, ${ }^{2}$ Department of Science and Technology Education, Faculty of Education, University of Jos, Nigeria \\ *Corresponding Author: mbozorji@yahoo.com
}

\section{ABSTRACT}

This study focused on assessment of colleges of education students' knowledge and attitudes toward solid waste management in the North Central zone of Nigeria. The cross-sectional survey design was adopted. A students' knowledge and attitudes toward solid waste management questionnaire were used to collect data from 1,800 students. The findings indicated that the students had a low knowledge level of solid waste management but their attitudes toward it were positive. A significant relationship was found between students' knowledge and their attitudes toward solid waste management. Furthermore, gender was shown not to have any significant influence on knowledge and attitudes of students toward solid waste management. It was concluded that although students had low knowledge of solid waste management, their attitudes toward it were positive. It was recommended that environmental education issues, especially, solid waste management should be incorporated into colleges of education curricula and properly taught for in-depth knowledge acquisition.

KEY WORDS: attitudes; gender; solid waste management; tertiary education

\section{INTRODUCTION AND REVIEW OF LITERATURE}

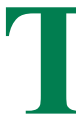

he waste management sector is facing numerous challenges globally. Huge amounts of municipal and industrial wastes are produced daily worldwide as a consequence of human activities. It is estimated that about 3.4-4 billion tons of municipal and industrial solid wastes and up to 300 million tons of hazardous waste are produced annually worldwide (Nabegu, 2010). As the volume and complexity of solid waste increase, the environmental risk posed by the waste products including human health risks, ecosystem degradation, contamination of soils and water, as well as, greenhouse gas emissions, global warming, and climate change become more serious (United Nations Environmental Programme, 2011). These risks are more obvious in the developing countries of the world where there are greater consumers of industrial materials, a higher percentage of outdated and obsolete technological products than in the developed countries. This is due in part to the waste products being shipped to developing countries, such as used refrigerators, hazardous industrial wastes, second-hand clothes, cars, and shoes among others (Ayodeji, 2010).

Solid waste refers to any garbage, refuse, sludge, and other discarded materials including solid, semi-solid, or contained gaseous materials, resulting from industrial, commercial, running and agricultural operations, and from community activities (New York State Department of Environmental Conservation, 2015). Solid wastes constitute the following materials when discarded: Paper bags, polythene bags, bottles, agricultural solid waste (tomato peels, cabbage, sugar cane, yam peels, etc.), waste tyres, scrap metal, latex paint, furniture and toys, garbage, appliances and vehicles, oil and anti-freeze, empty aerosol cans, and compressed gas cylinders, construction and demolition debris, and asbestos. Therefore, solid waste could be defined as non-liquid and non-gaseous garbage, refuse or sludge products of human activities, regarded as useless (Leton and Omotosho, 2004).

Over the past decade, most Nigerian cities have been grappling with the challenges of managing its solid waste because of the phenomenal growth of both population and waste generation. This is due to an annual increase in population and socioeconomic indicators as is documented in the Nigerian Population Census (NPC, 2008). It has been reported that the population in some States and Local Government areas is growing by as much as $20-30 \%$ per annum (World Bank, 2000; Ezeah, 2010). Solid waste management in cities and institutions of learning (i.e., colleges of education) is still in its infancy. Institutional and policy frameworks where they exist are not in line with global best practices. City specific data on waste necessary for planning are also not readily available (Akoni, 2007). Regrettably, waste collection and treatment do not seem to be adequate or even available Nigeria.

Nigeria, as a developing nation has put in a lot of effort aimed at managing solid waste, such as establishment of environmental agencies at the three tiers of government. For instance, in response to the serious challenges posed by the ravaging effects of pollution, deforestation, desertification, erosion, solid waste management, and sundry manifestation 
of environmental degradation, the Federal Government of Nigeria enacted the National Environmental Standard and Regulation Enforcement Agency (NESREA) Act of 2007 through the Federal Ministry of Environment to replace the Federal Environmental Protection Agency Act. The agency provides authority to ensure compliance with environmental laws, local and international, on environmental sanitation and pollution prevention and control through monitory and regulatory measures. At the State and Local government levels, State Waste Management Agencies/Boards, and Local Waste Management Boards are responsible for solid waste management.

Moreover, Environmental Education has been infused into basic and secondary schooling as cross cutting concepts. These efforts by the Nigerian government do not seem to have yielded the much-desired results as solid wastes are still seen in dumps in urban and rural regions. Review of available literature, for example. Akinbote (2007), Akoni (2007) show that most of the studies on solid waste management concentrate on household and communities with only a few on secondary school students as participants. Therefore, much still needs to be done to ensure environmental protection in Nigeria, particularly, with regard to solid waste management.

Furthermore, Environmental Education is not stated clearly in the vision of the Federal Ministry of Education. It is rather seen as a cross cutting theme within the nation's curriculum for both primary and secondary schools and the National Minimum Standards for colleges of education. Moreover, there is a paucity of studies on assessment of the knowledge level and attitudinal dispositions of individuals, particularly prospective teachers in tertiary institutions toward solid waste management in Nigeria. However, the question is whether the content of the National Minimum Standards offered to the students of colleges of education who are prospective teachers, adequately equips them with the knowledge and the right attitudes to carry out effectively the teaching and learning of environmental concepts, such as solid waste management. The colleges of education in Nigeria are also entrusted with the task of molding students to be responsible members of the society. It is crucial that teachers are the front liners in establishing and sustaining the culture of environmental consciousness in society (Akinbote, 2007), especially with regard to solid waste management. This agrees with the view of Ibrahim and Babayemi (2010) who emphasized that education should make young people aware of environmental problems. For this to be done in any significant way, there is the need to collect baseline data on students' understanding while in their teacher training programs. Particularly, their awareness about environmental problems and attitudes toward the solid waste management activities that are part of their learning process. Hence, the particular knowledge and attitudes gained from the environmental education would help in changing their behavior toward the environment. This is critical since teachers are implementers of government plans and policies.
Solid waste management is the collection, treatment and disposal of solid materials that are discarded because they have served their purpose or are no longer useful. Improper disposal of solid waste can create unsanitary conditions, and these conditions, in turn, can lead to pollution of the environment and the outbreak of vector-borne diseases, that is, diseases spread by rodents and insects. The task of solid waste management presents complex technical challenges. It also poses a wide array of administrative, economic, and social problems that must be managed and solved (Jerry, 2015).

Globally, the waste management sector is facing numerous challenges (Allen and Bassey, 2012). Allen and Bassey noted challenges from a lack of a declaration of national environmental emergency to a needed review and popularization of existing laws, regulation and policies. They also highlighted the need to encourage public participation at both the level of formulation and implementation and waste management planning for the entire nation covering all kinds of waste. In addition, Environmental Education needed to be integrated into the school curriculum right from primary school level, especially concerning recycling, reuse and waste disposal. Finally, ecological funds strictly monitored and used to remediate or restore damaged environment strict sanitation and waste management, reforestation, and oil spills clean up.

The importance of teachers' knowledge base in teaching cannot be underestimated. When emphasizing the importance of teachers in the effective implementation of Environmental Education, it is suggested that teachers have to be committed to teaching Environmental Education (Robottom et al., 2000). Apart from commitment, they also need a good knowledge base in Environmental Education. Knowledge is all about gaining a variety of experiences and acquiring a basic understanding of the environment and its associated problems. Knowledge is familiarity with someone or something, which can include facts, information, descriptions or skills acquired through experience, or education (Schratz, 2016).

Furthermore, Environmental Education has to do with a change of attitude, norms, values, beliefs, and awareness toward a friendly environment. Prospective teachers, who are future implementers of the curriculum of Environmental Education, need to have a positive attitude toward solid waste management. Attitude refers to acquiring a set of values and feelings of concern for the environment and the motivation for actively participating in environmental improvement and protection (Momoh and Oladebeye, 2010). Environmental attitude constitutes the provision of a good understanding of the set of beliefs, interest, or rules that influence pro-environmental action (Ballarityne et al., 2006). This presumes that if schools inculcate in children positive values and attitudes toward solid waste management they would take an active role in conserving the environment and its resources and hence preserve them for the future generation.

Research has shown that most of the studies on Environmental Education concerned preschool, primary, and secondary school 
students (Sama, 2003; Erol and Gezer, 2006; Kofoworola, 2007). However, no study was found to have investigated the variables of knowledge and attitudes of students of colleges of education in Nigeria in relation with solid waste management. Research has also shown that males have significantly better knowledge of Environmental Education than their female counterparts (Ibrahim and Babayemi, 2010). This finding is consistent with that of Kibert (2000) which showed a significant association between gender and environmental knowledge. However, insignificant differences were recorded across gender in the study by Rinmak (2010). These findings are inconclusive and justified the need for this study. Hence, this study was carried out to assess colleges of education students' knowledge and attitudes toward solid waste management in the North Central zone of Nigeria.

The specific objectives of the study were to investigate the level of students' knowledge of solid waste management, determine students' attitudes toward solid waste management and find out the relationship between knowledge and attitudes of students toward solid waste management. To achieve the objectives, the following research questions were investigated and hypotheses tested:

i. What is the level of students' knowledge of solid waste management?

ii. What are the students' attitudes toward solid waste management?

iii. There is no significant relationship between students' knowledge and their attitudes toward solid waste management.

iv. There is no significant difference between the attitudes of male and female students toward solid waste management.

\section{METHOD}

\section{Design}

The cross-sectional survey research design was employed in the study. The design was considered adequate because it was used to collect data from participants who had similar characteristics across a given geographical zone (North central zone of Nigeria) at a particular time. The participants were part three Nigerian Certificate in Education (NCE) students in colleges of educations in the North Central zone of Plateau State, Nigeria, whose knowledge and attitudes toward solid waste management were assessed at a particular time. A crosssectional survey research design according to Kazdin (2003) is a study in which participants are selected and assessed on a current or present variable of interest at a time. The design is, therefore, best suited for this study.

\section{Population and Sample}

The population for the study comprised 8,808 part three NCE students in 14 colleges of education in the North Central zone of Nigeria. The sample consisted of 1,800 part three NCE students from six colleges of education, which represented $20.44 \%$ of the population: Two federal colleges (with 1126 students), two state colleges (with 468 students), and two private colleges (with 206 students). The stratified sampling technique was used to select the study sample from six colleges of education used for the study by employing an appropriate sampling fraction of 0.02 in each school. A table of random numbers was used in selecting two colleges of education from each of the categories. To ensure that the foregoing was successfully carried out, the researchers employed the assistance of six research assistants comprising a lecturer from the Integrated Science Department of each of the six colleges selected for this study, who were trained by the researchers as research assistants with the consent of the authorities of the said colleges. The participants willing availed themselves to be used in the study.

\section{Instruments}

A students' knowledge and attitudes toward solid waste management questionnaire (SKATSWMQ) were used to collect data from the sample. The SKATSWMQ consisted of two subscales: Students' knowledge of solid waste management scale and Students' attitudes toward solid waste management scale. Each subscale had 20-item. The instrument was structured based on a five-point Likert scale ranging from strongly agree (SA), agree (A), undecided (UD), disagree (DA) to strongly disagree (SD). The values assigned to the options were 5, 4, 3, 2, and 1 for positive items (from SA to SD) and $1,2,3,4$, and 5 for negative items, respectively. Students with responses or scores of (4.00 and above) on the SKSWMQ and SASWMQ were regarded as having a high level, (3.00-3.99) as a moderate level of while (0-2.99) was regarded as having a low level.

The two subscale instruments were subjected to the scrutiny of three experts in the Faculty of Education of the University of Jos. The construct validity of each instrument was determined using exploratory factor analysis while their reliability indices were established as 0.83 and 0.89 , respectively.

\section{RESULTS}

Frequencies, means and standard deviations were used for answering the research questions. Pearson product moment correlation coefficients (r) and t-test statistic were used to test the hypotheses at the 0.05 level of significance. The results are presented based on the research questions and hypotheses as follows:

Research question one: What is the level of students' knowledge of solid waste management?

Table 1 summarizes that students with a high knowledge level of solid waste management had a frequency of 337 , representing $18.70 \%$, those with a moderate knowledge level had a frequency of 645 , representing $45.50 \%$, respectively. The results revealed that these college of education students generally had a low level of knowledge of solid waste management.

Research question two: What are the students' attitudes toward solid waste management? 
In Table 2, the results show that students' attitudes toward solid waste management were positive with a frequency of $947(52.60 \%)$. The percentage score of students that had negative attitudes was $47.40 \%$ and with a frequency of 853 .

Hypothesis one: There is no significant relationship between students' knowledge and their attitudes toward solid waste management.

In Table 3, the results show a significant but weak positive correlation between the college of education students' knowledge and attitudes toward solid waste management $(\mathrm{r}=0.44)$.

Hypothesis two: There is no significant difference between the attitudes of male and female students toward solid waste management.

The result in Table 4 summarizes that there was no significant difference between the mean scores of male $(\overline{\mathrm{X}}=69.18 ; \mathrm{SD}=8.21)$ and female students; $\overline{\mathrm{X}}=69.88 ; \mathrm{SD}=8.40$; $\left.\mathrm{t}_{1677}=0.149, \mathrm{p}>0.05\right)$. This null hypothesis was retained. Hence, there was no significant difference between the attitudes of male and female students toward solid waste management.

$\begin{aligned} & \text { Table 1: Analysis of students responses on the knowledge } \\
& \text { of solid waste management }\end{aligned}$
\begin{tabular}{lcc} 
Level & Range of scores & Frequency (\%) \\
\hline High & $76-100$ & $337(18.70)$ \\
Moderate & $57-75$ & $645(35.80)$ \\
Low & $0-56$ & $818(45.50)$ \\
Total & & $1800(100.00)$ \\
\hline
\end{tabular}

Table 2: Analysis of students attitude responses toward solid waste management

\begin{tabular}{lc}
\hline Attitude & Frequency (\%) \\
\hline Positive & $947(52.60)$ \\
Negative & $853(47.40)$ \\
Total & $1800(100.00)$ \\
\hline
\end{tabular}

Table 3: Correlation analysis between students knowledge and attitude toward solid waste management sores

\begin{tabular}{lccc}
\hline Variable & Number of students & $\mathbf{r}$ & p-value (two-tailed) \\
\hline Knowledge & 1800 & 0.44 & 0.003 \\
Attitude & 1800 & & \\
\hline
\end{tabular}

Significant at $\mathrm{p}<0.05$

Table 4: T-test analysis of the attitudes mean scores of male and female students toward solid waste management

\begin{tabular}{lcccc}
\hline Gender & $\begin{array}{c}\text { Number of } \\
\text { students }\end{array}$ & Mean \pm SD & df & p-value (two-tailed) \\
\hline Male & 977 & $69.18 \pm 8.21$ & 1677 & 0.14948 \\
Female & 762 & $69.76 \pm 8.40$ & & \\
\hline \multicolumn{4}{l}{ Not significant at $\mathrm{p}>0.05$} &
\end{tabular}

\section{DISCUSSION}

The study established a significant relationship between the knowledge of college of education students and their attitudes toward solid waste management. The results of this study revealed that college of education students generally had a low level of knowledge regarding solid waste management. Interestingly, this study experienced low mean scores in some items of the instrument below the average score of 3.00. These included responses to the disposal of waste around hostels areas, into gutters and some respondents were not aware of the fact that accumulation of solid waste could lead to the spread of diseases, flood when drainages are blocked and an unpleasant smell after undergoing the process of decomposition. This implies that respondents' knowledge level of solid waste management was not adequate. Burning of solid waste has harmful effects on the environment and the populace, it also causes ozone layer depletion; burning of solid waste leads to underground water pollution. This result is also in line with the findings of Lee and Williams (2001), Chi-Chung Ko and Chi-Kin (2003), Pulkkinen (2003) and Eguabor (2006) who all identified one of the barriers to the implementation of environmental education in colleges as lack of environmental knowledge among teachers.

The result in Table 2 summarizes that college of education students had a positive attitude toward solid waste management. It was observed that students generally recorded above the mean score as they indicated their willingness to contribute to the solutions of problems related to the environment. These are evident through the disposal of polythene and other solid waste materials, encouraged the use of waste bins and by buying products that do not encourage the accumulation of solid waste in the environment. This finding is in consonance with that of Magda et al. (2009) which showed that attitude was significantly related to students' level of knowledge before and following Environmental Education sessions. However, this result is contrary to that of Ibrahim and Babagemi (2010) who found negative environmental attitudes among some Nigerian secondary school teachers.

These findings show that individuals possess better attitudes when compared with knowledge (Kibert, 2000). Yet, factual knowledge about the environment is a precondition of one's environmental attitude (Ibrahim and Babayemi, 2010). Negative environmental attitude is contrary to the demands of solid waste management (Ebong, 2002).

\section{CONCLUSION}

Based on the findings of the study, it was concluded that college of education students in North Central Zone of Nigeria, had a low level of knowledge of solid waste management. The students also had positive attitudes toward solid waste management. It was further concluded that there was a significant relationship between students' knowledge of solid waste management and their attitudes toward solid waste management. Again, gender was found not to have any 
significant influence on the knowledge and attitudes of the college of education students toward solid waste management.

The findings of this study have identified gaps in the areas of knowledge as regard the knowledge level and attitudes of students, particularly prospective teachers, with regard to solid waste management. It was noted that these are areas that appear from the existing literature not to have received adequate emphasis in Environmental Education research. This is significant because of the position of prospective teachers who are the potential implementers of the Environmental Education curriculum.

The findings have far-reaching implications for teachers, teacher educators, educational researchers, science associations, institutions/governments/agencies, companies and individuals that concerned with science and environmental education, among others. For instance, relevant institutions/policy makers should ensure that Environmental Education should be stated clearly in in the vision of the Federal Republic of Nigeria and given the attention it deserves. Environmental Education should be made a core course and not just have its concepts infused here and there in school curricula. Important issues on environmental education especially solid waste management should be built and incorporated into the school curriculum of each discipline at all tiers of education, that is primary, secondary and tertiary levels to create awareness/knowledge and acquisition of favorable attitudes toward environmental issues and problems, particularly, solid waste management for a sustainable environment. Institutional frameworks should be made to align with global best practices. There should be reviews and regularization of regulations and policies to encourage teachers' participation both at the level of formulation and implementation.

In planning for instruction, teachers should show or itemize what learners need to know in Environmental Education, how learners are to achieve the intended goals, what teachers need to do to help students develop the required knowledge, and attitudes in the context in which teaching and learning occur. Teachers should be knowledgeable in Environmental Education issues and teach students with commitment and appropriate and engaging strategies and activities that will improve students' acquisition and development of favorable attitudes toward solid waste management and other Environmental Educationrelated issues.

There should be training and re-training of science teachers through series of workshops, seminars and symposia on environmental issues and problems as well as how to come up with effective pedagogy in handling the teaching and learning of solid waste management practices in colleges of education. Students of colleges of education should take part in formal and informal education classes to promote their knowledge and attitudes toward solid waste management to equip them for sensitizing and inculcating such attitudes and values to the learners they will teach. Researchers should embark on various aspects of environmental problems, particularly as to the effects on Fauna and Flora with a view of proffering solutions and their research findings and recommendations disseminated to relevant agencies.

Science associations at national and international levels should mount conferences and workshops for the purpose of sensitizing teachers and teacher educators on various aspects of environmental/education and hazards, as well as, and their incorporation into school curricular through dissemination of communiques from such activities to relevant agencies and organs of government for policy decisions and implementation.

Companies should be sensitized on the dangerous effects of indiscriminate and improper disposal of solid wastes and the need to employ environment-friendly strategies such recycling of industrial waste products through relevant agencies and defaulters sanctioned.

\section{REFERENCES}

Akinbote, O. (2007). Some Nigerian primary school pupils' knowledge, attitude and practices on water pollution. The Social Science, 2(1), 283-286.

Akoni, J. (2007). Municipal Solid Waste Management in Abuja. Abuja, Nigeria: Abuja Environmental Protection Board.

Allen, F., \& Bassey, N. (2012). Making Policies Work: Between Environmental Policies and Environmental Protection. Nigeria: Oilwatch.

Ayodeji, I. (2010). Exploring secondary school students' understanding and practices of waste management in Ogun State, Nigeria. International Journal of Environmental and Science Education, 5(2), 201-215.

Ballarityne, R., Connell, S., \& Fien, J. (2006). Students as catalysis of environmental change: A framework for researching intergenerational influence through environmental education. Environment Education Research, 12(3-4), 413-427.

Chi-Chung, K.A., \& Chi-Kan, L.J. (2003). Teachers perceptions of teaching environmental issues within the science curriculum: A Hong Kong perspective. Journal of Science Education and Technology, 12(3), 187204.

Ebong, R.D. (2002). Appraisal of knowledge and attitude of the 'Akwa Iboms' toward a sustainable environment in Nigeria. Environmental Health Perspectives, 110(4), 211-212.

Eguabor, V.O. (2006). Some suggestions on resources for teaching environmental education in secondary schools. In: Nzewi, U., (Ed.), 47 ${ }^{\text {th }}$ Annual Conference Proceedings of the Science Teachers' Association of Nigeria. Ibadan, Nigeria: Heinemann Educational Books (Nigeria) Plc. pp. 207-210.

Erol, G.H., \& Gezer, K. (2006). Primary students' teachers' attitudes towards the environmental issues. International Journal of Environmental Science Education, 1(1), 65-77.

Ezeah, C. (2010). Design of a Municipal Solid Waste Management Strategy for the City of Wolverhampton (M.Sc. Thesis, University of Wolverhampton). Available from: http:/www.wlv.ac.uk. [Last accessed on 2017 Jun 19].

Ibrahim, F.M., \& Babayemi, O.F. (2010). Knowledge and attitude of a group of Nigerian undergraduates towards environmentalism. Global Journal of Environmental Research, 4(1), 47-53.

Jerry, A.N. (2015). Solid Waste Management. New York: Encyclopedia Britannica, Inc.

Kazdin, A.E., (Ed.), (2003). Methodology: Why is it so important. Methodological Issues and Strategies in Clinical Research. Washington, D.C: American Psychological Association.

Kibert, N.C. (2000). An Analysis of the Correlations between the Attitudes, behavior and Knowledge Components of Environmental Literacy in Undergraduate University Students. (M.Sc. Dissertation, University of Florida). Available from: http://www.cce.ufl. Edu/Nicole-kibertthesisformatted.Pdf. [Last accessed on 2017 Jun 19]. 
Kofoworola, O.F. (2007). Recovery and recycling practices in municipal solid waste management in Lagos, Nigeria. Waste Management, 27(9), 1139-143.

Lee, J.C.K., \& Williams, M. (2001). Researching environmental education in the school curriculum: An introduction for students and teacher researchers. International Journal of Research in Geographical and Environmental Education, 4(10), 218-244.

Leton, T.G., \& Omotosho, O. (2004). Landfill operations in the Niger Delta region of Nigeria. Engineering Geology, 73(1-2), 171-177.

Magda, M.S., Hesham, M.N. \& Rim, A.H. (2009). Environmental education and its effect on the knowledge and attitudes of preparatory school students. Journal of Egyptian Public Health Association, 84(3-4), 344-367.

Momoh, J.J., \& Oladebeye, D.H. (2010). Assessment of awareness of attitude and willingness of people to participate in household solid waste recycling programme in Abo-Eketi, Nigeria. Journal of Applied Science in Environmental Sanitation, 14, 1-12.

Nabegu, A.B. (2010). An analysis of municipal solid waste in Kano Metropolis, Nigeria. Journal of Human Ecology, 31(2), 11-119.

National Population Commission (NPC). (2008). 2007 Population Census Figures. Abuja. Available from: http://www.population.gov.ng. [Last accessed on 2017 Jun 19].

Pulkkinen, K. (2006). Teacher Thinking and Practice in Environmental Education: Finnish Northcaselian Primary School Teachers as Environmental Educations. Sustainable Development through
Education. Proceeding of the International Conference on Environmental Education, Helsinki. U.S.A: McGraw-Hill Publishing Company. pp. 143-154.

Rinmak, R.H.L. (2010). Attitudes of Women Towards Environmental Degradation in Plateau State: Implication for Environmental Education. (Unpublished Ph.D. Thesis, University of Jos. Available from: http:// www.unijos.edu.ng. [Last accessed on 2017 Jun 19].

Robottom, I., Malone, K., \& Walker, R. (2000). Case Studies in Environmental Education: Policy and Practice. Geelong: Deakin University Press.

Sama, E. (2003). Teacher candidates' attitudes towards environmental issues. Gazi University Journal of Education, 23(2), 99-110.

Schratz, M. (2016). Austria: Overcoming a bureaucratic heritage as a trigger for research on leadership in Austria. In: Anlesing, H., Day, C., \& Johansson, O., editors. A Decade of Research on School Principals: Cases from 24 Countries. Dordrecht, Netherlands: Springer. pp. 307329.

United Nations Environmental Programme (UNEP). (2011). Towards a green economy. Pathway to Sustainable Development and Poverty Eradication. Nairobi: United Nations.

World Bank. (2000). Infrastructure-urban development. In: The Proceedings of African Regional Conference of Cop Grading Urban Slums Held from October, $3^{\text {rd }}, 5^{\text {th }}, 2000$, Johannesburg, South African. Available from: http://www.worldbank.org. [Last accessed on 2017 Jun 19]. 